\title{
Literature
}

\section{DECEMBER 1989 AND THE CONCEPT OF REVOLUTION IN THE PROSE OF ROMANIAN WOMEN WRITERS}

\author{
Monica MANOLACHI \\ University of Bucharest, Romania \\ e-mail: monicamanolachi@yahoo.com
}

\begin{abstract}
Whenever the topic of revolution is at stake nowadays, Romanian people from different walks of life usually think of December 1989. The tragic events that led to the regime change have left a permanent mark on many people's lives. Many contemporary writers and critics have written about it, but there is still a long way until the individual and the cultural trauma is healed. Since little has been published in English about the literary work of contemporary Romanian women writers, this paper aims to culturally translate the subject and to provide insights into their perspectives. From a theoretical point of view, it explores the perceptions of the concept of revolution seen either as a change of direction (a moment in time) or as a cyclical process (a flowing gyre). The selected corpus includes: a poetic novel, The Fox Was Ever the Hunter by Herta Müller; a diary, The Witnessing Wall by Florența Albu; a novel made of individual stories, One Sky Above Them by Ruxandra Cesereanu; a family chronicle, The Immigrant from Biggin Hill by Lăcrămioara Stoenescu; and a first-person retrospective novel, Fontana di Trevi by Gabriela Adameșteanu. Each of them tackles the idea of revolution in a distinct manner, which suggests the existence of a literary corpus by women writers that resonates in various ways with the original conflict and contributes significantly to its cultural memory.
\end{abstract}

Keywords: contemporary Romanian prose; 1989 Revolution; women's writing; conceptual history; cultural memory;

When Romanian critics try to explain why Romanian writers have avoided the theme of the 1989 Revolution, they often refer to the rapport between ethical and aesthetic motivations: in front of collective death, intellectuals remain silent. Writers are overcome by history, detest old-style politics and ideology, cannot keep up with the rhythm of socio-political change, they fear the subject might lead to low quality literature and fiction may not be the best approach. To express such a major shift adequately, a new language must be invented. How to be authentic when the audio-visual 
means of communication have already produced an overwhelming mix of reality and fiction? Fortunately, there have been exceptions: writers who may have not radically rethought the literary canon, but who have stuck to writing anyway and constantly searched for a suitable language based on both traditional and modern sources.

Many historians hesitate to define the 1989 events as revolution. The best approach is to be critical, they say. For example, in Key Concepts of Romanian History, editors Victor Neumann and Armin Heinen (2013) suggest that out of over five hundred history books, only a few can be called true stories. They warn these books deal more with retrospective anticommunist debates, with people's loyalty to the regime, with external factors that favoured totalitarianism, but they do not question the persistence of conservative and anti-modernist ideologies, they do not really explain the social, economic and political causes of people's discontent, the post-1989 lack of civic spirit, people's dependence on power structures and the general absence of individual ideals, the reasons why people cooperated with totalitarian regimes or the disconnection between the elites and the masses. In their view, very few of these studies tried to approach key-concepts anew, very few reinterpreted the concept of revolution, for example. Neumann and Heinen draw on the perspective of Reinhart Koselleck (2002) on the concept of revolution, to highlight that the twentieth-century theory of history developed tools which can better explain modern historiography. They demonstrate the Romanian concept of revolution has had its own avatars and mere conceptual approximations are not enough to explain Romanian historiography. They suggest there should be a revolution within the very theory, methodology and concepts used by historians. More precisely, their proposal is to depart from former Romantic views and endorse contemporary, more pragmatic Western methodological norms.

According to Koselleck (2002), the concept of revolution in its modern sense has acquired several meanings over the past five centuries. Originally used by astronomers such as Nicolaus Copernicus to describe orbital or axial motion, the concept was adopted as a metaphor to describe socio-political changes and phenomena, especially beginning with 1789 , ever since it has become vulnerable to ideologies. At first, it meant a short turbulent event that could lead to the overthrow of one form of government and its replacement with another, a meaning which echoes its premodern manifestations. Later, it was viewed as a long-term structural change, understood either as a reform or as an evolution. Koselleck considers it a metahistorical concept which combines both singularity and echo, both synchrony and diachrony, both cognition and performativity, both progress and return. Its implicit theoretical premises are duration, reiteration, evolution and innovation, but their proportions differ from one context to another. 
In December 1989: the Deconstruction of a Revolution, Ruxandra Cesereanu (2004) proposes a synthesis of theories: the theory of pure revolution, the theory of conspiration, and a hybrid theory that conflates the ideas of revolution and coup d'état. In the introduction, we find an inventory of the adjectives attached to it in the publications of the time:

\begin{abstract}
"usurped, hijacked, aborted, stolen, robbed, confiscated, manipulated, recycled, failed, betrayed, desecrated, cheated, made-up, sanitized, polluted, shadowed, radio-controlled, staged, tainted, shot down in flames, charged, murdered, assassinated, fired, arranged, seized, abandoned, unfinished, incomplete, altered, dubious, ambiguous, tangled etc." (Cesereanu, 2004: 7).
\end{abstract}

This list of epithets (which in Romanian have feminine desinences) strikingly proves the revolution has been compared with nouns such as: a state, an object, a feminine subject, an idea, a space, a substance or an activity (mainly a show). This obvious reification of a moment in history, correlated with a long record of negative meanings, functions as a symptom of collective trauma. To place the concept of revolution in perspective, Cesereanu's book provides a genealogy of the working class revolts in the 1970s and the 1980s and a review of the historiography that deals with the trial and the execution of the presidential couple, the issue of the so-called terrorists, and the role of the army in the events.

A decade later, however, considerations such as that "literature in times of revolution almost never translates in a literary revolution" (Manolescu, 2015: 3) echo French historian Albert Thibaudet, whose point of view may be true when the idea of revolution is seen as a violent political change. Who can write literature in times of bloodshed? Nonetheless, if conceived as a gradual structural change, a revolution could be accompanied by valuable literature.

In Literature and Revolution: the December 1989 Revolution in the Romanian Novel, writer and journalist Iulian Cătălui (2016) proposes an indepth survey on the relationship between novels and revolution. Without referring to Koselleck, he offers a genealogy of the concept of revolution from Platon to Romanian French philosopher Emil Cioran and American sociologist and political scientist Theda Skocpol. Relying on multiple sources, he proposes a larger understanding of the concept, which is close to Koselleck's perspective:

„Any revolution, more or less violent, bloody or radical, must or should represent first a revolution understood as hope and spiritual, cultural, philosophical, intellectual, religious and moral evolution, and then as a political, social and economic one. [...] The revolution- 
metamorphosis [...] presupposes profound qualitative changes that involve a country, a nation, a system or a political regime, starting from the very original, astronomic meaning of the term, 'change of direction"” (Cătălui, 2016: 15).

Although a formula such as "revolution as soul's elevation" (17) may sound compelling, when it comes to its relationship with literature, Cătălui's brief analysis of the post-1989 Romanian novel dwells on previous analyses to maintain the decade of the 1990s was not favourable to quality literature. Moreover, he explains why publishing houses and the public were mainly interested in formerly censored works, memoirs, diaries, books of history and interviews that describe life in the communist prisons and in deportation camps. His conclusion that the 1989 events are a "generous subject" raises serious ethical questions and partially undermines the purpose of the study itself, because instead of showing how literature deals with the collective trauma that paralyzed the society, the critic is more preoccupied to defend the thesis that what happened was a revolution, "'a rite of passage' to an open, free and democratic society" (439). Although he agrees with other critics that writers may not have found the best language yet and that there may be a gap between what authors write and what readers need, he eventually hopes to see better works. By and large, however, women's writing does not play a significant role, even though the critic mentions in passing a number of contemporary women novelists, whereas women diarists or memorialists are simply left out.

This disproportional gender ratio appears in other works. For example, 1989 Revolution Street is a commemorative collection of essays coordinated by writers Dan Lungu and Lucian Dan Teodorovici (2009). Out of twenty contributors, only four are women: poet Magda Cârneci, actress Maia Morgenstern, journalist Cristina Popescu and French translator Laure Hinckel. The problem is not women writers have nothing to say, but that the idea of proportional contribution from a gender point of view is neither an aim nor a criterion.

In her article entitled "The Image of Revolution in Romanian literature", critic Sanda Cordoș (2019) surveys some of the works in which significant writers from Dimitrie Cantemir and Ioan Budai Deleanu to contemporary novelists tackle the subject. She demonstrates the existence of a literary tradition in which the image of the revolution as a socio-political reality appears like a red thread. The literary milestones of this tradition are related to three main historical sources: the national revolution from 1848, the social revolution that bridges the nineteenth and the twentieth centuries, and the popular revolution of the 1989. On the one hand, the first and the last are considered as moments in time reflected in literature per se, as historical 
turning points, with the difference that whereas the revolutionaries from 1848 played an active conspiring part, those from 1989 were rather manipulated by invisible hands. On the other hand, the long progression of the social revolution is presented as a source for a variety of approaches. The article begins with examples of class-conscious works by authors such as Nicolae Filimon and Dimitrie Bolintineanu. It then touches interwar literature that shows the increasing gap between the rich and the poor. It goes on with covering communist literature in which the representation of the revolutionary spirit used to be a duty, up to becoming a cliché. And it also offers glimpses into works that present the social revolution from alternative perspectives that question its ideals and the figures of its representatives. However, one drawback of this study is that it refers to works predominantly by male writers (more than $80 \%$ ), which may suggest that, in general, the topic has not been actually relevant to Romanian women writers.

Taking into consideration such views, this article argues that contemporary Romanian women writers who have covered the subject in question to a certain extent have not been exceptions, but are part of a significant group of authors who care about both personal and collective memory. The authors and titles included in the study represent a series of possible narrative directions: The Fox Was Ever the Hunter (1992) by Herta Müller, a poetic chronicle of the last months of 1989; The Witnessing Wall (1994) by Florența Albu, a diary with a last section of first-hand impressions about December 1989; One Sky Above Them (2013) by Ruxandra Cesereanu, a novel based on extensive historical research; The Immigrant from Biggin Hill (2016) by Lăcrămioara Stoenescu, a novel in which the reference to the regime change plays a relevant role; and Fontana di Trevi (2018) by Gabriela Adameșteanu, a novel about many characters, some of whom took part in the events.

The novel The Fox Was Ever the Hunter (1992) by Herta Müller, initially published in German and available in Romanian since 2009 and in English since 2016, tells the story of several young men and women caught in the totalitarian machinery over the last months of the Cold War, illustrating the 1989 socio-political change at the level of the common man. Although the city is not mentioned from the beginning, the account is set in Timişoara, a place where the Nobel Prize winner lived in her youth.

Adina, a schoolteacher, and Clara, an engineer in a wire factory, are friends. Adina's former lover, Paul, is a doctor and a musician involved in composing songs, including songs against the regime, whereas Clara's lover, Pavel, is a secret agent, a married man, who infiltrates and reports on the 
group. The two women fall out when Adina has enough reasons to suspect Pavel is the one who has been visiting her apartment and cutting off the limbs of a fox fur rug she keeps in her bedroom. It is a sign she is being tracked, because she is friends with the members of a music band that have composed and performed a song entitled "Face Without Face." Its lyrics are a far cry from the propaganda songs that praise the party, the leader and the nation: "Face without face/Forehead of sand/Voice without voice/Nothing is left except for time/Time without time/What can you change..." (Müller, 2016: e-book) When the secret agents hear it on the stage, they order the evacuation of the theater, since their job is to eliminate any form of culture that represents a threat to the establishment. Whereas men are taken to the secret police office to be interrogated, women are terrorized in their own apartments. Cutting off the fox's limbs, one at a time, when Adina is not at home shows the psychotic tactics employed by the representatives of the secret police to keep people under control.

The novel begins as a Kafkaesque puzzle of surreal events, apparently disconnected from each other, in which the human spirit is softened and absurd paranoia is projected on witnessing objects, fauna and flora. The author often uses sophisticated poetic techniques to paint various instances of everyday life in the late 1980s dictatorship in a provincial city, which used to be part of the former Austro-Hungary until 1918. Primary school children do volunteer work harvesting tomatoes, factory workers struggle to survive the failed national industrialization project, intellectuals attempt to find creative ways out of the corrupt and suffocating atmosphere. The second part of the novel sets in contrast these literary illustrations and the figure of the dictator, Nicolae Ceaușescu, in power from 1965 to 1989, whose propagandistic portrait spreads through each and every corner of private life.

The role of Müller's specific metaphoric language was described as "a shared weapon of oppression and resistance", "much more than a stylistic device", it was pointed out that her "poetic vision is an essential component of dissidence" and four types of metaphoric approach against the unjust force of totalitarianism were identified, "shifts and reversals, particulation, colouration and linkages" (Eddy, 2013: 88-89). These language devices were probably meant, firstly, to create a psychological individual survival kit against fear and, secondly, to raise consciousness on the effects of an aging political regime, ruled by an aging dictator, supported by an aging oppressive apparatus. All these struggles at textual level mirror an accumulated tension and a gradual increase in awareness regarding the rotting rapport between individuals and the state.

The metaphor of the fox functions as a literary instrument used to deconstruct particular layers of power structure. Known for its opportunistic hunting style, the fox is also a hunted animal in Müller's novel. Alive or 
dead, it represents now the oppressors, now the oppressed, now the powerful, now the powerless. When she was a child, Adina was taken to a man who sold fox furs. His physical description suggests his identification with the animal: "The man's hair and beard and hairs on his hands were as red as the fox. His cheeks too. Even back then, fox and hunter were one and the same." (Müller, 2016: e-book) However, nobody asks foxes if they want to be hunted, there are no historians to tell their point of view. As an owner of the fox fur, Adina shares the statute of a hunter too, whereas later she is hunted by the state secret police. Her friend Clara too is hunted by Pavel, they have a love affair, but she is also a hunter, because she accepts him, she becomes pregnant in the hope of benefiting from a better social status. The secret service officer Pavel hunts people who threaten the regime, but he is also a victim of it, especially when the regime is overthrown, and he decides to leave the country. The dictator himself practised hunting during his life, and he was hunted to death over the last days of his life. The name choice for the two most important male characters, Paul and Pavel, hints at the possibility of someone turning from a prey into a hunter and vice versa.

Although it is not mentioned straightforwardly, the last eight chapters refer to the 1989 Revolution started in Timișoara. The episodes include only hints about it: the opera house, the cathedral, the police and their dogs, the morgue, sealed coffins, soldiers etc. Adina seems rather detached, afraid, but able to picture the military actions taking place in the city, while she and Paul are hiding in the countryside: "And she imagines the dictator has seen the spreading city from high in the air, and that he's ordered the army to surround it. And that the soldiers are shoveling away, cutting off the spreading city, building a moat without a single bridge." (Müller, 2016: ebook)

Instead of focusing on the absolute full grande histoire and on frontline heroes, Müller preferred the antiheroes and their incomplete petites histoires, lived by most people. Instead of depicting the main events from the days of the revolution, her option was to expose a growing range of absurd situations and everyday incidents that caused the mass revolt which led to the removal of the regime, by employing the power of storytelling and innovative poetic energies based on surrealist literature and art.

In 1970, poet and journalist Florența Albu started what would later be published as The Witnessing Wall (1994), after she had undergone a heart surgery. At the age of 36 , she wrote the first lines of what is now one of the diaries that describe the everyday life over the last two decades of communism: dreams; writers and their works; the meaning of writing in 
times of censorship; family relationships and friendships; the exploration of feelings; encounters with different people, including representatives of the secret police; urban versus rural life; letter extracts; criticism and selfcriticism; references to TV and radio programmes; journeys in the country or abroad; the 1977 earthquake; the events of 1989-1990 etc. The tone is elegiac and sad, her attitude pessimistic, reserved or apocalyptic, sometimes enthusiastic, but rarely humorous, whereas the constant present tense keeps the flame of her consciousness alive. A solitary woman, she considers her diary a daily capriccio, an imaginary site where she can exercise personal freedom and aesthetic virtuosity.

Of particular interest are its last tens of pages, in which the general obsession with the end of the regime takes over her remarks. For example, in July 1989, she has a premonitory dream: Ceaușescu and his projection on the wall of a hall, both crumbling in front of the audience. Listeners are at first happy and then, all of a sudden, terrified by the resurrection of both real politician and his image, who continues his discourse, unaware of what has just happened. Later on, in November, she protests in her diary against the simplistic rhyming poems she reads in the literary magazines she is proofreading: they still praise the regime. She also makes notes about the political changes from other Eastern European countries and soliloquizes about the stale socio-political atmosphere, in which many people feel desperate and depressed. Food exists only in the groceries from the city centre and gas is provided mainly in the central areas where foreigners are accommodated. In rest, cold and hunger.

On December 20, she makes a relevant observation to what is about to come: "The insane is delivering a speech again. He has just returned from Tehran. He's ranting and raving. I turn off the radio." (Albu, 1994: 431) The moment when the ruling pair flies away in their private helicopter and the ensuing violent events determine her to start a new section in her diary:

"I am in front of the first clean white page - Anno Domini 1989, December 21 .

After Timişoara, Bucharest and the rest of the country have risen and the First Year of another history has started. I begin to say History again, without the fury, the shame and the despair that have dominated me over the past years, without the sarcasm, the bitterness and, again, the shame that have been crushing me lately, when thinking of this bloody time we have been given.

In the morning of another day, towards the end of December, I think we lived the most terrible rebirth of our times: a few days that assuage our guilt, that wash away our cowardice and partial revolts.

We have lived the revolution, this 'crusade of the youth and the children', as it has been called; their flame has consumed me, I have 
burnt and resurrected through their sacrifice. I think I may die now: I have received the grace of their sacrifice." (435).

The descriptive vocabulary - "circle", "rebirth", "revolt", "revolution", "crusade" - indicates she perceives more than socio-political aspects. The universality of "circle" and "rebirth", the premodernity of "revolt" and the religious resonance of "crusade" suggest an emotional radiography of the moment, which expresses both materiality and immateriality, both reality and illusion, her attempt to go beyond everyday facts.

One critic has mentioned Albu's subsequent disenchantment, labelling her book as "a symptom of disillusion experienced first hand" and "a convincing example about the deceiving nature of words" (Goldiș 2016: 16). Indeed, she is upset with the violence and the chaos from the city centre. Even though she is in the street, she does not identify with the crowd. Instead, she notices how people have destroyed one of the pine-trees from the Revolution Square. Another horrifying aspect for her is the film of the mock trial and the execution of the two communist leaders on the Christmas day. As some of her entries clearly suggest, she was a religious person and could not have accepted the idea of staged murder.

One month later, she equates the revolution with a mere revolt, denouncing the false pathos that followed. Whereas in the years before 1989 she witnesses what she calls an empty time, afterwards she feels the end of history has arrived. She is content she has lived to see the end of three obsessive decades, but she believes the miracle has not defeated the evil and the throes will continue. At the age of 55 she is tired to continue the fight, but hopes the new generations will build a more respectable future, wash away the shame and, most important, not forget. In May, just before the first free general elections, she notes: "This history is a chronotope of quicksand: it swallows everything and one must always start all over again. God, let it be different from now on!" (Albu, 1994: 457) The Mineriad that follows after the unsuccessful elections is described in postcolonial terms: "The miners have invaded the city. They were called by Iliescu, to defend the government and 'the revolutionary achievements'. An army of Calibans, one dirtier than the other, some 'dressed-up' as miners, to be more authentic." (466) Since she lives close to the University Square, she provides first-hand impressions of the atmosphere from the city centre as she becomes aware of her estrangement reaching collective proportions: "No, such setting ourselves on ourselves has never happened before!" (467)

What brings her joy and peace of mind is a stroll with one of her exiled friends on the streets of Bucharest. A former rural doctor, her friend tells her about an Oltenian countryside woman, who once gave birth to a child after a day of work, was too tired to expel the placenta and soon fell asleep. 
Consequently, the doctor had to take it out without the mother's help. Albu compares the revolution with a baby born by a peasant mother who is too tired and risks an infection or even death if her inert body is not attended to with great care.

In the course of 1990, she is concerned with how the heroes are commemorated. For instance, in the summer, she believes "to remember them today, to still say 'revolution' in this calm chaos - a blasphemy!", whereas in the winter, although she is disappointed that not many people come to commemorate the dead, she insists on the exceptional character of the brief but intense moment of freedom, "I don't think I will ever live a day of purification like 21 December 1989 again." (472)

In general, her diary presents revolution not only as the violent replacement of one political regime with another. Her enthusiasm is not that of the revolutionaries who died in the street or of those who agreed on the dictatorial couple's execution, but of someone who hopes in a better world, inhabited by people who do not destroy trees, who can travel abroad and enjoy freedom of speech. Twenty years of alienation make her compare the events with the 1977 earthquake. When she depicts the nocturnal atmosphere from the University Square, where one could hear the bullets and the church bells, she is rather detached. Moreover, the reference to the 1989 events constitute only about a tenth of her diary, which suggests the socio-political circumstances of the day were rather the background of an inner reality - her poetry and her writing in general - more important than anything else, as some of her entries imply. This is supported by the choice of the title: The Witnessing Wall is a metaphor of the book understood as a stone on which the writer carves a text and a metaphor of someone who intermediates between incompatible worlds.

The novel One Sky Above Them (2013) by Ruxandra Cesereanu is a collection of portraits of both victims and oppressors, young and old, followers, rebels or outcasts of the communist regime, including a wide range of individual accounts occurred between 1945 and 1991 and based on documents, memoirs, interviews, history books, secret service files, oral history, newspapers etc. The days of December 1989 are devoted to representative figures that echo the author's historiographic research: the death of two young men, the execution of the presidential couple and the chief of the secret police's role in the events. Whereas the two young men have good chances to be considered martyrs in a conflict they did not want, the chief of the secret police and the presidential couple are monstrous caricatures.

On the one hand, the two young men fall victims of their own enthusiasm, unaware of the mortal dangers they are exposed to. Călin, a 19- 
year-old student from Bucharest who participates in the events behind the barricade, has a dream one day: "He was climbing a ladder made of knives, he was simply climbing a ladder made of knives, when he was awoken from his whirlpool dream that morning with no snow, although winter had already arrived or it should have arrived." (Cesereanu, 2013: 170) The day in question is December 21, and he happens to be in the city centre, where people have gathered from all over the capital. Lost in thought, he witnesses how the world suddenly turns upside down: "Romania is a fictional country, Călin mused, when a sudden thump, followed by the stampede and the cries of the passers-by, shook him out of his lethargy." (173) The student hears the first news about the change from a female demonstrator: "The revolution has started, shouted a woman wearing crumpled clothes. It is then when Călin woke up, as if he had heard those words for the first time. Finally, he knew what to do in this world." (174) When the author mentions Călin joins the people who have built one of the barricades, she compares the coat of arms of the Romanian flag with a woman's belly: "The hacked and beaten belly of our country. Its womb torn to ribbons because of so many abortions." (174) When bullets reach Călin's body, the description of the tragic moment is three-fold. Firstly, the physical sensation of excruciating pain is compared with the bite of a piranha. Secondly, he is compared with a bullfighter in an arena, where the red of life and the black of death are meant to color the tense atmosphere and to evoke a premodern approach to conflict. Thirdly, he is associated with Saint George fighting against the dragon, trying to reach the sky, but eventually defeated because there is no rope or ladder leading upwards. All images represent confrontations between human values and animal instincts and the social element is equated with a single brutal and ruthless body. The story suggests social body, the same as any body, is made of members, organs, parts. Failing to care about and nurture any of them may lead to dysfunctions and collapse.

Iasmin, a 25-year-old friendly womanizer from Bucharest, who calls himself El Campeón, grew up in a poor working-class family, watching video-taped movies featuring actors such as Arnold Schwarzenegger and Tom Cruise, which makes him dream of "great battles, heroic scenes, war camaraderie and mysterious adventures" (190). Although scared by the death toll of the first days of the armed conflict, he takes to the streets and heads to the building of the state TV station, the only one at the time, to defend it against the so-called foreign terrorists. Inspired by historical heroes such as Alexander the Great or Napoleon or by movie characters such as El Zorro or D'Artagnan, he assumes his time has come to demonstrate his own courage: he prepares Molotov cocktails, but he does not know for whom. Surrounded by increasing rumours about supposed terrorists, he receives a gun to defend the entrance to the institution. Two days later, his shoulder is slightly 
wounded, and he is transported to a hospital, where he begins to rant and babble under the effects of medicine. The social and political psychosis is so great and the confusion so widespread that one of the nurses believes he is a foreign terrorist and denounces him. A few days later, he suddenly dies of a heart attack, not before someone unknown has written on his chest: TERRORIST. In principle, the story of Iasmin illustrates how mass media can be a double-edged sword, especially when a closed society ruled by questionable propaganda for many decades lays itself open to a world in which mass media are free. Watching historical or adventure movies about superheroes fighting battles that they usually win may be one of the ways to learn about manhood and bravery, to boost your morale and self-esteem. In contrast, watching breaking news about strong men in flesh and blood who fight real battles and eventually joining those battles in your city is a way to learn about and sometimes prepare yourself to make the supreme sacrifice.

On the other hand, Cesereanu spares no effort in satirizing the political leaders in brief slashing chapters. Those about the rise and fall of Coana Leana (the popular nickname of Elena Ceaușescu) and about the bad stammer of Şoșescu or Mosio Lio Prezido (the Romanian transliteration of the French pronunciation of Ceaușescu and Monsieur le Président) are meant to demystify their huge symbolic power, gradually accumulated over more than two decades of state propaganda. But probably the most caustic chapter is that about the leader of the secret police from 1989, General Iulian Vlad. The figure of Iunian, his grotesque caricature, aims at condemning the oppressive role of the institution, not only during the days of the revolution, but also throughout the communist decades. Having heard Ceaușescu and his consort have died, he elaborates a list of absurd fictitious excuses that may stand as public explanations for the tragedies which have just happened and which he cannot control anymore. His part includes an inventory of eight preposterous hypotheses about the provenance of the terrorists. When he is considering which one to choose to present to the public, he appreciates that "it was not necessary for the terrorists to have an identity or to exist in flesh and blood, it was enough to unleash a psychosis" (186). He is depicted as the moronic initiator of this socio-political psychosis, because he phones several garrisons from the capital and sets them against each other, which eventually leads to bloodshed. The story of Iunian is a trenchant critique directed at a specific type of leadership during communism, which proves its imperfections and weaknesses and reminds us of "The Emperor's New Clothes" by Hans Christian Andersen. No matter how invisible secret services pretend to be, the effects of their activities are visible and there will always be a child to cry out: "But the Emperor has no clothes!"

The general impression of One Sky Above Them is that the revolution as a traumatic social event came after more than four decades of incomplete 
social revolution, in which individual freedom mattered much less than the liberties of the ruling class, hence the most relevant slogan of the time: Freedom! Since the December 1989 political crisis ended in carnage, this author too interprets the Romanian Revolution as a kind of abortion in "a country where pregnancies had to be terminated and babies killed if they were not desired and loved" (111), which conceptually dislocates the issue again, moving it from the macro level of the socio-political sphere to the micro level of personal and family issues, with few representations of the meso level that was actually confiscated by the central power before 1989 . The author's final remarks - "the stories were lying in me, collected for many years, waiting to macerate, like the grapes for cognac" (233) - convey that it takes time and patience to understand the meaning of collective death and to dare to approach such a sensitive subject.

For the protagonist of the novel The Immigrant from Biggin Hill (2016) by Lăcrămioara Stoenescu, December 1989 constitutes a rather distant milestone. Nonetheless, the idea of revolution as a change of direction at personal level pervades the whole narrative. On the whole, the author's main concern is to show the apparently invisible connections between an individual's revolt and a socio-political upheaval, and how these links influence family relationships. The book also presents the possibility to compare and contrast the pre-1989 and the post-1989 regimes and lifestyles, to discover how individual sensitivity reverberates to oppression, revolution and freedom.

Victoria Negru, a young engineer who works in a Romanian factory in the mid-1980s, makes the decision to leave the country and join her husband Gabriel, who has already found a decent well-paid job in the United Kingdom. She has a toddler and is full of hope. However, the local agents of the secret police attempt to prevent her from departing, intoxicating her with provocative remarks about her husband. Unfortunately, they are right as Gabriel does not love her anymore when they reunite in London two years after his departure. The summer of 1989 is when their divorce is officially pronounced, somewhere in the Dominican Republic, where Gabriel knows the taxes are low. Victoria begins to see his true colours when he abruptly announces her he is marrying the daughter of a wealthy businessman, and they are moving to the United States.

Later on, Victoria makes friends with some English people from Biggin Hill, an area of South East London where she continues to live with her son. Mary, one of her neighbours, volunteers to take care of her little boy when she is at work. When Victoria feels obliged to reciprocate her generosity, Mary reassures her: "You too will help others as soon as you become able to." (Stoenescu, 2016: 272) In the same summer of 1989, Victoria decides to 
visit her family in Romania, and she invites Mary and two other English friends to join her. Victoria's temporary return to Romania is an occasion for the author to briefly refer to those months when "everyone hoped for the polenta to explode, for the Romanian people to become free too, for communism to fall" (277). The succinct presentation of the regime change and its aftermath resembles a page in a history book for secondary school, with no mention of the fatalities:

"In the last part of the year 1989, people witnessed those long-awaited historical events that reconfigured the continent and changed the existence of both Western and Eastern Europeans. For Romania, the end of 1989 meant the beginning of freedom. Major transformations followed and the most important was that communism was replaced with capitalism, which eventually proved to be savage. Ever since then, people have been going through a long and never-ending period of transition. For decades now, the population has hardly been able to live in the conditions of this new epoch." (277).

Nevertheless, what is relevant to the novelist is that the political news about the 1989 and 1990 events spreads quickly in the Western Europe and foreign journalists begin to transmit reports about the level of poverty in provincial hospitals, orphanages and slums, which eventually makes many charities send humanitarian relief. In 1990, Victoria learns about two such charities existing in Biggin Hill, cooperates with them as an interpreter and travels to her home country, to the towns of Comănești and Dărmănești, Bacău county. Her volunteering and enthusiasm are not short-lived as she becomes a regular participant in the activities of the two charities that have continued to operate up until the present day. After she makes friends with Patrick Whelan, an Englishman of Irish origin, they join forces and travel to Romania together. Patrick learns Romanian and obtains a driving licence that allows him to transport tons of relief supplies to the children in need from Bacău county over the following years. The poor children's joy and positive energy make her realize that volunteering is like a therapy for her and eventually grasp the meaning of Mary's ecclestiastical advice: "Do good to others and expect nothing in return." (325). The only drink Victoria and Patrick manage to find in a local small shop gains sentimental value: one of his deepest wishes is to drink that particular type of rose champagne at their own wedding.

In contrast with her ex-husband Gabriel, who only in a few years becomes the administrator of his father-in-law's commercial estates in Connecticut, United States, Patrick supports Victoria's wish to alleviate the life of the sick and the destitute from her country of origin. In her case, the 
concept of revolution seen as a gradual change of direction means that the social work she does on a voluntary basis transforms the concept of the social itself. The socialist propaganda and the top-down communist strategies pursued to combat difficult social community problems is being replaced with a British approach to social work, rooted in post-war decades of grassroots initiatives, applied modern social theory and a favourable political climate for the sustainable development of charities. Moreover, the social is not only nationally circumscribed; it becomes international through the motivation of individuals who care about people in need from elsewhere, within a common legal framework that allows citizens from one country to help citizens from another country.

Another representation of revolution is based on the concept of nation, which is integrated and repositioned in an international context. In parallel with Victoria's journeys from Romania to the United Kingdom and back, Stoenescu defends the importance of knowing one's family tree. Although the protagonist is born and bred in Bucharest, the reader finds that her family tree is actually transnational. The author evokes a hussar named Simion in the personal army of Emperor Franz Joseph, who falls in love with Gisela, a girl who lives in a monastery from Sighetu Marmației. The presentation of the nine children they have, born in different places of the Austro-Hungarian empire, depending on where the hussar's military post was (Prague, Vienna, Chernivtsi, Kosice and Selyatyn), is an occasion for the novelist to weave together personal histories and the great History of the first half of the twentieth century, in order to prove the existence of Victoria's European lineage before the European Union was constituted as a political body. Although not born abroad, she is drawn to travel across the border from an early age. In 1972, when she is twelve, her mother applies for a visa to visit her brother in Germany. Victoria hopes to join her mother, but she is refused a visa, after she has sent three letters to her uncle, which decades later she is appalled to discover in her secret service file. It is only after Victoria becomes a student in the early 1980s that she can travel with her friends to several countries from the Eastern Bloc. Therefore, from an early age, the West becomes "the forbidden fruit in her imagination" (25), which later motivates her to follow her first husband in the United Kingdom in spite of all obstacles and to survive the nervous breakdown caused by their divorce. With this complementary plot, the novel advocates for healthy international relationships in which relatives, especially families with children, can travel freely, without risking estrangement, divorce or other types of loss. 
In Fontana di Trevi (2018), Gabriela Adameșteanu puts forward the views of an elderly woman on some of the causes and the effects of the December 1989 events. Letitia Branea is also the protagonist of two previous novels, The Equal Way of Every Day (1975) and Wasted Morning (1983), which allows the author to reestablish links with the provisional past and to review the rapport between history and private life. Whereas the setting in the first two parts of the trilogy is in Romania, in the third part we find a post1989 Letiția living in a French village as an émigré, visiting her lifelong friends from Bucharest from time to time. However, the novel "is not a book of postcommunist Romania, but a book of memory [...] about the reconciliation with the past, not about exile" (Crețu 2018: online). The daughter of a postwar political convict, Letiția has relatives who lost their wealth during communism, and she is now trying to recuperate parts of it. Her portrait as a kinetotherapist and wannabe writer is the result of selfreflection and insights about the others, which makes the truth about the past rather tentative, multifaceted. One such circumstance is December 1989, but the idea of revolution is represented not only as a regime change, but also as a systematic return on different levels: personal, social, political, economic, cultural etc.

Although the younger characters play less prominent roles in comparison with the more experienced ones, Claudia Morar, who is the daughter of Letitia's hosts in Bucharest and her goddaughter, is found in the middle of the street during the revolutionary turmoil. On December 21, when she and her boyfriend Șerban decide to go to the cinema, they come across the soldiers brought by the authorities in the city centre. The boy is thrilled "Cool! More exciting than in Star Wars!" "It's started! See? It's started! I've told you!" (Adameșteanu 2018: 35) - and proves to be naïve as he joins the group of protesters. The girl is naïve too at first, thinking being allowed to chant Freedom! and other slogans against the regime equals a sort of festivity, but she soon separates from him and immediately discovers what she sees is "a terrible dream she had to get out of" (38). After the boy is killed in an ambush, she feels guilty and weak.

The author recreates the post-December 1989 atmosphere from multiple contrasting perspectives. The traumatized adolescent Claudia and her family visit Rome in the spring. Her parents Sultana and Aurelian suddenly become supporters of the anti-communist regime. Her godmother Letiția doubts the revolutionary character of the events. Her godfather Petru tells Claudia's father: "We shouldn't spit on our life spent during communism, because all those who are opening their eyes now will come one day and spit us in the face!" (47) Harry Fischer, a revolutionary, declares: "There are teenagers in all revolutions, their brain hasn't yet developed a spirit of conservation." (48) Petru's former wife turns back to Bucharest to 
recuperate her grandparents' fortune, whereas Claudia finds Șerban's mother bereaved in the Revolution Heroes Cemetery.

On the one hand, Adameșteanu's focus is predominantly on Claudia's parents and their generation. Some still live in the country, some live abroad, and their constant smouldering conflict is a source for quite a few chapters that weld national and diaspora issues together. Letiția witnesses how Sultana and Aurelian take part in the neocommunism-free zone, a place in the University Square where people deliver speeches: "Is it normal to deliver speeches about the death of someone dear?' I asked Aurelian. 'What else can one do?' he replied confused." (43). In private, Sultana explodes: "You, who live abroad, don't think there is anything good here, because you would not have reasons to motivate your departure! You don't recognize the Revolution either, because you missed it." (25). From abroad too, Petru Arcan, Letiția's husband, represents the academic voice: "The revolution masquerade exhumed the Old Guard of the Stalinist old guys, baptized them as dissidents and thus nobody has seen the blood on their hands!" (24). He also comments with cynicism that a political revolution without bloodshed is no revolution. In a conversation with her French psychotherapist, Letitia herself admits she is extremely interested in the agony caused by such harrowing events: “'Since you love it, you can't go over your trauma,' Aurélie used to tell me. 'I love it because it offered me a subject for a novel,' I told her one day, laughing bitterly." (71).

On the other hand, Claudia grows up among adults who long to live a free life, but who cannot relinquish their guilt-laden past. Her life abroad emerges from Eastern Europe to Italy and then to the United States as a monstrous extension of their wishes. Their politically-conditioned and dwarfed intimacy during communism is transferred to her young spirit, almost confiscating it. Claudia is portrayed as merely a pretext to exhibit many anxieties of Letiția's generation. The narrator does not invest much in Claudia's private life. Her parents call her Grumpy to explain her lack of communication. The reader is not given any clue about why the teenager feels burdened immediately after Șerban dies. When she meets Șerban's mother in the cemetery, Claudia does not shed any tear, does not try to console her in any way. It is curious that, although she seems to have a successful academic career, she is denied any inner life from start to finish. She is only the subject of mere gossip among her parents and family friends, as if she did not have her own will. She is given no chance of understanding her own guilt complex and recovering from her own trauma. Perhaps this is Adameșteanu's means of throwing down the glove to younger generations of novelists who might approach the subject.

Nonetheless, what Adameșteanu produces with "political clarity" (Mironescu, 2018: online) is a chronicle of small individual failed 
revolutions. The collage of fragments about a variety of characters reveals the depth of cynicism, the lack of empathy and cold pragmatic views. The book closes with the news that the trial of the 1989 Revolution reopens, which operates as an invitation to reconsider the past individually. How to do it is another question and depends on each and everyone. The title Fontana di Trevi may be an answer, as it is a symbol of returning to Rome, which for Romanians means returning to their Latin origins, and a metaphor of emigration at large. Perhaps revolution as return, considered in as many ways as possible, is the main idea of the novel. The author implies that confronting one's past periodically, individually and collectively, no matter how terrible it was, often is a condition for a healthier life.

The violence and the mass unrest that wounded the socio-political body at many levels in December 1989 have produced an imaginary universe and a higher level of awareness, which Romanian literature and the arts have been gradually absorbing and interpreting. With these five works that address the topic of the 1989 regime change, we have seen that the rapport between historical truth and private life has been extremely important for Romanian women writers. In addition, the works discussed differ in terms of voice, genre and perspective as the five authors expressed their sensitivity to collective trauma in distinct ways.

In summary, Herta Müller used the power of surrealist poetry to create vigorous prose as a form of resistance and struggle against a totalitarian regime. Rich in various figures of speech, orchestrated by a highly omniscient narrator and based on the symbol of the fox, seen as both prey and hunter, her poetic novel illustrates revolution mainly as a constantly inquisitive and intensely imaginative mental process.

A sample of what was called drawer literature, Florența Albu's diary offers an inward-looking and sometimes lyrical detailed account of life during communism. Her periodic temperate return to the white page is counterbalanced by the drastic political change from December 1989, which sets private and public life in sharp contrast.

In her research-based novel, Ruxandra Cesereanu made an exercise of empathy by portraying both victims and oppressors, to produce a fresco of factually relevant Romanian histories from the second half of the twentieth century. The concept of revolution as a political shift is illustrated through the poignant portrayals of the secret police leader and two young men, victims of the upheaval.

Lăcrămioara Stoenescu's chronicle delineates the effects of several historical turning points on the members of a family and their close-knit transnational relationships. Although the 1989 Revolution as a political 
change is only briefly represented, the book emphasizes revolution through social innovation and the restoration of humanistic values.

The unreliable narrator from Gabriela Adameșteanu's first-person retrospective novel offers a down-to-earth outlook of an elderly émigré on the so-called 1989 Revolution. Based on the technique of literary collage, it stages both some of the violent events from Bucharest and various recurrent responses to a range of personal and collective traumas, with a frankness and a vigour that invites younger generations to reflect on the subject as well.

All things considered, this essay is part of the much larger process in which the History and a variety of small histories are combined, in which various individual histories are brought together through the philosophy of history, and in which the range of individual contingent histories may contribute to the ways in which history is conceptualized. In this context, literary history as a form of cultural memory plays a significant function.

To leave aside women writers' role in this process is to obliterate half of it and to forget about revolution as a cyclical process or as panta rhei. In this context, the study of the relationship between revolution and literature by men and women allows a fairer practice of aesthetic reflection, the identification of the moral roles of history in people's everyday life, and the possibility to construct hypotheses and test what is conceived and endorsed as reality.

\section{References:}

Adameșteanu, G. (2018). Fontana di Trevi. Bucharest: Polirom.

Albu, F. (1994). Zidul martor/ The Witnessing Wall. Bucharest: Cartea Românească.

Cătălui, I. (2016). Literatură și revoluție. Revoluția din Decembrie 1989 în romanul românesc./ Literature and Revolution. The 1989 Revolution in the Romanian Novel. Bucharest: IRRD.

Cereseanu, R. (2009). Decembrie '89. Deconstrucția unei revoluții./ December 1989. The Deconstruction of a Revolution. Bucharest: Polirom.

----. (2013). Un singur cer deasupra lor/ One Sky Above Them. Bucharest: Polirom.

Cordoș, S. (2019). Imaginea revoluției în literatura română/ The Image of Revolution in Romanian Literature. Revista Vatra, no. 6-7, p. 135-139.

Goldiș, A. (2015, August 20). Ficțiune vs. non-ficțiune. Reprezentări ale Revoluției din 1989 în literatură/ Fiction vs. Non-Fiction. Representations of the 1989 Revolution in Literature. Cultura, no. 30, p. 16-17.

Koselleck, R. (2002). The Practice of Conceptual History: Timing History, Spacing Concepts (T. S. Presner et al., Trans.) Stanford: Stanford University Press.

Lungu, D.; L. D. Teodorovici (Eds). (2009). 89 Strada revoluției/ 89 Revolution Street. Bucharest: Polirom.

Manolescu, N. (2015, October 30). Revoluție și literatură/ Revolution and Literature. România literară, no. 45. 
Mironescu, D. (2018, November 22-28). Iar adevărul nu ne face liberi/ And Truth Does Not Make Us Free. Dilema veche, no. 770. Retrieved April 12, 2020, from https://dilemaveche.ro/sectiune/carte/articol/iar-adevarul-nu-ne-faceliberi

Müller, H. (2016). The Fox Was Ever the Hunter (P. Boehm, Trans.). London: Granta Books. (Original work 1992) Retrieved April 12, 2020, from https://www.ebooks.com/en-ao/2545385/the-fox-was-ever-the-hunter/philipboehm-herta-m-ller/

Neumann, V.; A. Heinen (Eds). (2013). Key Concepts of Romanian History: Alternative Approaches to Socio-Political Languages (C. D. Mihăilescu, Trans.). Budapest \& New York: CEU Press. (Original work 2010)

Stoenescu, L. (2016). Imigranta din Biggin Hill The Immigrant from Biggin Hill. Bucharest: Tracus Arte.

Eddy, B. D. (2013). A Mutilated Fox Fur: Examining the Contexts of Herta Müller's Imagery in Der Fuchs war damals schon der Jäger. In Brigid Haines and Lyn Marven (Eds.), Herta Müller (pp. 84-98). Oxford: OUP. http://dx.doi.org/10.1093/acprof:oso/9780199654642.001.0001 